\title{
Vulvar Cancer pT1 TNM Finding v7
}

National Cancer Institute

\section{Source}

National Cancer Institute. Vulvar Cancer pT1 TNM Finding V7. NCI Thesaurus. Code C89422.

Invasive vulvar cancer confined to the vulva or perineum. (from AJCC 7th Ed.) 